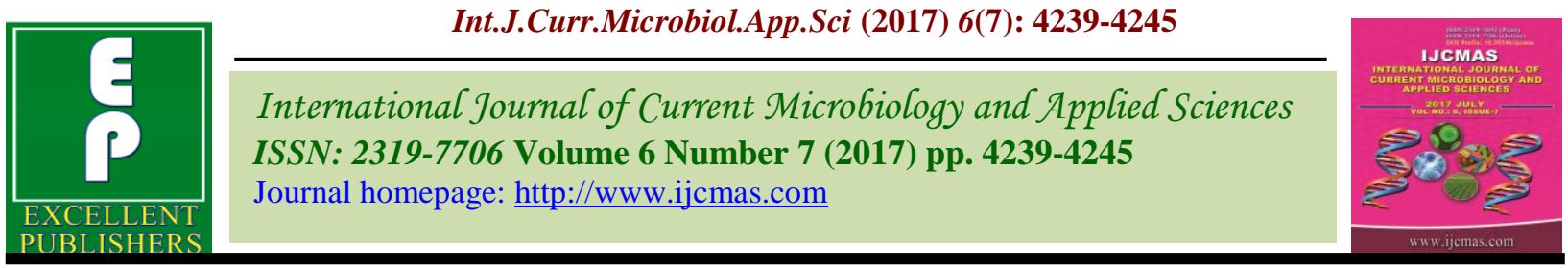

Original Research Article

https://doi.org/10.20546/ijcmas.2017.607.439

\title{
Determinants of Capital Formation in Agriculture: Hadoti Region of Rajasthan, India
}

\author{
Pradeep Joliya*, V. Kamalvanshi, Saket Kushwaha and Shilpi \\ Department of Agricultural Economics, Institute of Agricultural Sciences, \\ Banaras Hindu University, India \\ *Corresponding author
}

\section{A B S T R A C T}

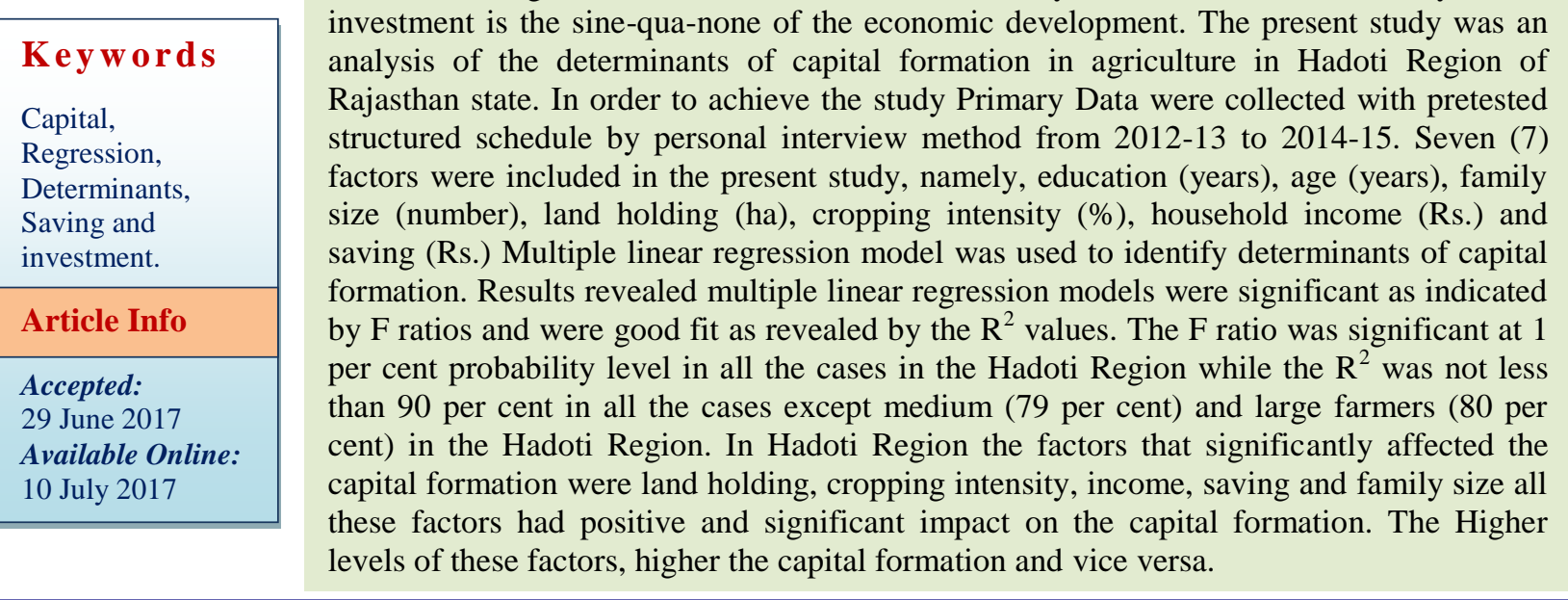

\section{Introduction}

A broad definition of capital would include, besides physical durable assets, the circulating working capital and the human resources in organizing the economic activity. However, the study of capital formation includes only those tangible assets which can be used for further production in which, it has characteristics such as facility of transferring stock into flow services, facility of transferring stock into income over time and improving productivity over time (Yadav, 2002). The rate of return on private investments, which in turn depends on the terms of trade and technology, is found to be the most important determinant of private capital formation. The second most important determinant of private investment is the addition of new farm holdings. As most capital assets are indivisible and perfect sharing is not possible, addition of new farm holdings, resulting mainly from the division of holdings, necessitates investments in new farm buildings, machinery, etc. Institutional credit supplied to agriculture as short-term or medium- and long term loans was found to be another determinant of private capital formation (Chand and Kumar, 2004). Singh and Sidhu (2005) also reported that increase 
in depth of water table, gross cropped area, real contribution of livestock and volume of output from crops and terms of trade exerted positive significant effects on private investments. A number of socio-economic factors influence private investment in agriculture. Some of the important factors are; age and education of the farmer, size of family, size of holdings, type of crops grown and their productivity, credit facilities and terms of credit, level of irrigation, power supply, proximity to input and output markets, level of returns to investment, government support in the form of subsidies and other concessions Mahantesh (2012). Singh (1970) observed that there was a very high significant correlation between size of farm and capital formation. Singh and Mishra (1974) considered size of holdings and irrigation as the factors influencing capital formation in agriculture. The larger the portion of current output invested in capital assets by the cultivating families the greater would be the increase in production and the rate of growth (Murukannaiah, 2006). Mishra and Chand (1995) argue the behaviour of public and private capital formation in agriculture and also examine the efficiency of capital use in agriculture. They conclude that the efficiency of capital use in Indian agriculture shows continuous improvement since the seventh plan (1985-90).

The performance of the agriculture sector influences the growth of the Indian economy. The growth of agriculture and allied sectors is still a critical factor in the overall performance of the Indian economy. As against the Twelfth five Year Plan's (201217) target of 4 percent growth for the agriculture and allied sectors, the growth registered was 4.2 per cent in 2013-14,-0.2 per cent in 2014-15 (Economic Survey, 2015). The Gross Capital Formation (GCF) in agriculture and allied sectors as a proportion to the Gross Domestic Product (GDP) in the sector stagnated around 14 per cent during 2004-05 to 2006-07 the again from2007-08 to 2009-10 it showed a great marked movement from 16.1per cent to 20.1 per cent and a downfall in $2010-11$ of 18.5 per cent. Now again coming up to 2011-12 to 2013-14 it has shown a decreasing trend of 18.3 per cent to 15.1per cent. However, there is a marked improvement in this figure during the five year plans (Economic Survey, 2014). There is a need to significantly step up investment in agriculture, both by the private and public sectors to ensure sustained target growth 4 per cent per annum. Agricultural development has many facets- technical, organizational, financial, demographic, sociological and capital formation. Income, savings and investment are the three key variables of an economy while investment is the sine-quanone of the economic development. It is savings which provide the where-withal for investment. The level of income is also an important variable as it determines savings and investment whereas past investment in capital goods, in turn, determines the present level of income. The low level of income and economic stagnation in developing countries are attributed to meager stock of capital per head of population and low rate of capital formation. The present study was an analysis of the determinants of capital formation in agriculture in Hadoti Region of Rajasthan state

Rajasthan is the largest state of India constituting 10.4 per cent of total geographical area and 5.67 per cent of total population of India. The state is divided into 7 divisions, 33 districts, which are further subdivided into 244 tehsils, 249 panchayat sammitees and 9,168 gram panchayats. The major crops grown in different parts of Rajasthan are bajra, wheat, jowar, maize, cotton, rapeseed and mustard, groundnut and horticultural crops (Swain et al., 2012). The one of the key drivers of agricultural growth 
is the Gross Fixed Capital Formation (GFCF) in agriculture as a percentage to Agri-GDP. The GFCF in agriculture \& allied sector as percentage of agri-GDP has more than doubled during last decade at all India level (GOI, 2012a). As per advance estimates, the real Gross State Domestic Product (GSDP) at Constant (2011-12) Prices for the year 201617 is likely to attain a level of ' 5.83 lakh crore, as against $` 5.46$ lakh crore in the year 2015-16 showing an increase of 6.71 per cent in the year 2016-17 against the growth of 6.64 per cent in the year 2015-16. The real Gross Value Added (GVA) at Constant (2011-12) Basic Prices for the year 2016-17 is likely to attain a level of ' 5.53 lakh crore, as against 5.19 lakh crore for the year 2015-16 showing an increase of 6.62 per cent in 2016-17 against the growth 6.38 per cent in 2015-16. At the end of the year 2015-16, the total assets at current prices are estimated to be $2,36,428$ crore, which is 35.15 per cent of the GSDP ( $6,72,707$ crore). The Gross Fixed Capital Formation (GFCF) in the year 201516 increased by 11.54 per cent over the previous year 2014-15. The corresponding sectoral growth rates are 6.37 per cent in Agriculture, 4.19 per cent in Industry and 8.41 per cent in Service sector in the year 2016-17 over 2015-16. Total Gross State Domestic Product (GSDP) in 2015-16 was 6.64 per cent to 6.71 per cent in 2016-17 at current price 2011-12 (Economic Review Rajasthan, 2016-17).

\section{Materials and Methods}

Rajasthan is the largest state of Indian continent covering an area of 3.42 lakh sq. $\mathrm{km}$. The state is administratively divided in to 33 districts. Out this Hadoti region was selected because it is highly irrigated due to Chambal River and Kali Sindh and has canals for irrigation in areas of Kota and Baran and Jhalawar. These districts are agriculturally advanced. This region comprises of four districts and all four have been selected (Kota, Baran, Bundi and Jhalawar). A three stage random sampling technique was adopted for the selection of block, villages and farmers from Hadoti region of Rajasthan state. This region comprises of four districts and all four was selected these districts are agriculturally advanced and from each district one block was selected using simple random technique. Again from each selected 3 villages were selected using simple random techniques. From selected 12 villages from each village 16 farmers were selected 4 from each category of farmers (Marginal, small, medium, large) and total 192 farmers were selected to use simple random sampling.

\section{Source and period of data}

The study was based on Primary data. Primary Data was collected with pretested structured schedule by personal interview method from the period of 2012-13 to 201415.

\section{Analytical tool}

Multiple Linear Regression Model was used for analyse the Determinants of capital formation in agriculture. Functional form of Multiple Linear Regression Model is as follows

$\mathrm{K}=\mathrm{b}_{0}+\Sigma \mathrm{b}_{\mathrm{i}} \mathrm{X}_{\mathrm{i}}+\mathrm{u}_{\mathrm{i}} \quad$ (i=1 to 7$)$

Where,

$\mathrm{K}=$ Capital Formation in Agriculture ('000 Rs.)

$\mathrm{X}_{1}=$ Education (Years)

$\mathrm{X}_{2}=$ Age (Years)

$\mathrm{X}_{3}=$ Family size (No.)

$\mathrm{X}_{4}=$ Land holding (ha)

$\mathrm{X}_{5}=$ Cropping intensity $(\%)$

$\mathrm{X}_{6}=$ Income ('000 Rs.)

$\mathrm{X}_{7}=$ Saving ('000 Rs.) 
$b_{0} \& b_{i}=$ Intercept and Slope Coefficients of the Regression Model, respectively, $\mathrm{u}_{\mathrm{i}}=$ Random Disturbance Term.

\section{Results and Discussion}

\section{Determinants of capital formation}

There are certain critical factors which influence capital formation in agriculture in general. To study the Hadoti Region, these factors have been identified based on a priori knowledge and the review of literature pertaining to capital formation.

In all, seven (7) factors were included in the present study, namely, education(years), age(years), family size(number), land holding(ha), cropping intensity(\%), household income(Rs.) and saving(Rs.) Multiple linear regression model was employed to estimate the relationship of these factors.

The overall adequacy of the model was tested through $\mathrm{F}$ ratio and $\mathrm{R}^{2}$, which appeared to be fairly good in all the categories of the farms.

In Hadoti Region all the farm size categories, the multiple linear regression models were significant as indicated by $\mathrm{F}$ ratios and were good fit as revealed by the $\mathrm{R}^{2}$ values (Table 1). The $F$ ratio was significant at 1 per cent level in all the cases in the Hadoti Region while the $\mathrm{R}^{2}$ was not less than 90 per cent in all the cases except medium ( 79 per cent) and large farmers (80 per cent) in the Hadoti Region. In Hadoti Region the factors that significantly affected the capital formation were land holding, cropping intensity, income, saving and family size all these factors had positive and significant impact on the capital formation. The Higher levels of these factors, higher the capital formation and vice versa.

However, the determinants that influenced capital formation varied amongst farm size categories. In the Hadoti Region, the factors that significantly influenced capital formation were land holding, cropping intensity, income and saving in the case of marginal farmers, land holding, income and saving in the case of small farmers, land holding, income and saving in the case of medium farmers and land holding, cropping intensity, income and saving in the case of large farmers.

Table.1 List of selected districts, blocks, villages and number of respondents in Hadoti region

\begin{tabular}{|l|c|c|c|}
\hline $\begin{array}{l}\text { Name of the } \\
\text { districts }\end{array}$ & Name of the blocks & Name of the villages & $\begin{array}{c}\text { Number of the } \\
\text { respondents }\end{array}$ \\
\hline Kota & Ladpura & Anvatkheda & 16 \\
\cline { 3 - 4 } & & Hathikheda & 16 \\
\cline { 3 - 4 } & & Madaniya & 16 \\
\hline \multirow{3}{*}{ Baran } & \multirow{2}{*}{ Anta } & Balakheda & 16 \\
\cline { 3 - 4 } & & Alipura & 16 \\
\cline { 3 - 4 } & & Ratadiya & 16 \\
\hline \multirow{3}{*}{ Bundi } & \multirow{2}{*}{ Bundi } & Jharbalapura & 16 \\
\cline { 3 - 4 } & & Nayagaon & 16 \\
\cline { 3 - 4 } & & Narsinghpura & 16 \\
\hline \multirow{2}{*}{ Jhalawar } & \multirow{2}{*}{ Jhlarapatan } & Alawa & 16 \\
\cline { 3 - 4 } & & Durgapura & 16 \\
\cline { 3 - 4 } & & Borda & 16 \\
\hline
\end{tabular}


Table.2 Determinants of capital formation of different size of farms in Hadoti region

\begin{tabular}{|c|c|c|}
\hline Variable & Regression coefficient $(\beta)$ & t-value \\
\hline \multicolumn{3}{|l|}{ Marginal Farmers } \\
\hline Constant & -7.045 & -1.518 \\
\hline Education(Years) & .075 & .878 \\
\hline AGE(Years) & .015 & .511 \\
\hline Family size(No.) & .193 & 1.267 \\
\hline Land holding (ha) & $9.984 * *$ & 2.526 \\
\hline Cropping intensity (\%) & $.032 * *$ & 2.501 \\
\hline Income('000 Rs) & $.117 * * *$ & 7.387 \\
\hline Saving('000 Rs) & $.236 * * *$ & 8.358 \\
\hline \multicolumn{3}{|l|}{$\mathbf{R}^{2}=.979$} \\
\hline \multicolumn{3}{|l|}{ F-value $=269.39 * * *$} \\
\hline \multicolumn{3}{|l|}{ Small Farmers } \\
\hline Constant & $-27.62 * * *$ & -3.53 \\
\hline Education(Years) & 0.10 & 0.27 \\
\hline AGE(Years) & 0.08 & 1.37 \\
\hline Family size(No.) & -0.19 & -0.50 \\
\hline Land holding (hec.) & $23.32 * *$ & 2.61 \\
\hline Cropping intensity (\%) & 0.01 & 0.99 \\
\hline Income(Rs/000) & $0.16^{* * *}$ & 3.15 \\
\hline Saving(Rs/000) & $0.21 * * *$ & 5.01 \\
\hline \multicolumn{3}{|l|}{$\mathbf{R}^{2}=.958$} \\
\hline \multicolumn{3}{|l|}{$\mathbf{F}$-value $=131.57 * * *$} \\
\hline \multicolumn{3}{|l|}{ Medium Farmers } \\
\hline Constant & $-194.98 * * *$ & -3.51 \\
\hline Education(Years) & 0.75 & 0.59 \\
\hline AGE(Years) & 0.54 & 1.08 \\
\hline Family size(No.) & -1.92 & -0.69 \\
\hline Land holding (hec.) & $68.54 * * *$ & 5.03 \\
\hline Cropping intensity (\%) & 0.10 & 0.53 \\
\hline Income(Rs/000) & $0.14^{*}$ & 1.69 \\
\hline Saving(Rs/000) & $0.17 *$ & 1.89 \\
\hline \multicolumn{3}{|l|}{$\mathbf{R}^{2}=.794$} \\
\hline \multicolumn{3}{|l|}{$\mathbf{F}$-value $=22.001 * * *$} \\
\hline \multicolumn{3}{|l|}{ Large Farmers } \\
\hline Constant & -55.422 & -.536 \\
\hline Education(Years) & 3.513 & 1.112 \\
\hline AGE(Years) & 1.051 & 1.478 \\
\hline Family size(No.) & $-11.510^{* * *}$ & -3.298 \\
\hline Land holding (hec.) & $22.158 * *$ & 2.675 \\
\hline Cropping intensity (\%) & .084 & .311 \\
\hline Income(Rs/000) & $.090 * *$ & 2.552 \\
\hline Saving(Rs/000) & $.199 * * *$ & 2.855 \\
\hline \multicolumn{3}{|l|}{$\mathbf{R}^{2}=.804$} \\
\hline F-value $=23.425 * * *$ & & \\
\hline
\end{tabular}

Note: ***,*** indicates significance level at $1 \%, 5 \%$ and $10 \%$ respectively 
The finding of the current study is in conformity with finding of Singh (1970), Sing and Mishra (1974) and Murukannaiah (2006). Singh (1970) reported that in all size group of farms land holding, income, saving and cropping intensity significantly affected the capital formation (Table 2). According to Singh (1970) capital formation in agriculture in Haryana state, considered size of farms as an influencing factor, results revealed that there was a very high significant correlation between size of farm and capital formation and Singh and Mishra (1974) considered size of holdings and irrigation as the factors influencing capital formation in agriculture in Bihar. The study analyse that per farm investment showed an increasing trend with increase in size of holding the similar result was found in Hadoti regions. Bartels (1999) observed that that difference in farm size and structure were a more important determinant of farm income than education and that heavy investment in education could not be justified for the income that could be achieved from a small farm. Chand and Kumar (2004) suggested that rate of return on private investments, which in turn depends on the terms of trade and technology, is found to be the most important determinant of private capital formation. The second most important determinant of private investment is the addition of new farm holding the current study in Hadoti region showed land holding was one of the most critical determinants of capital formation. Sidhu (2006) in their findings observe that the capital accumulation depends on the rate of investment, which in turn depends on the rate of savings.

As expected, all these factors had positive and significant impact on the capital formation. As indicated by the significance of the ' $t$ ' value, land holding was the most important factor that contributed to capital formation in the Hadoti Region.
In conclusion, Determinants that influenced capital formation varied amongst farm size categories. In the Hadoti Region, the factors that significantly influenced capital formation were land holding, cropping intensity, income and saving. The results revealed that per farm investment showed an increasing trend with increase in size of holding the similar result was found in Hadoti regions. The second most important determinant of private investment is the addition of new farm holding the current study in Hadoti region showed land holding was one of the most critical determinants of capital formation. The efforts, so far, on large and medium farms by way of increased credit has borne fruits with increased capital formation on these farms while much attention is needed for marginal and small farm categories. This calls for sustenance of these efforts coupled with strengthened extension facilities and educating these farmers on importance of capital assets and further boosting the marginal and small farms by ways or organising them in groups towards better rural economy, in general.

\section{References}

Anonymous, 2014. Economic Survey, Ministry of Finance, Government of India.

Anonymous, 2015, Economic Survey, Ministry of Finance, Government of India.

Anonymous, 2017, Economic Review Rajasthan, Directorate of Economics, Rjasthan.

Bartels, H., 1999, the structure and factors determining human capital formation in agriculture. Inderdusziplinare Studien Zur Entwicklung in Landlichen Raumen, 14: 265.

Chand, R., and Kumar, P., (2004), "Determinants of Capital Formation and Agricultural Growth: Some New 
Explorations", Economic and Political Weekly, 39(52):5611-5616.

Mishra, S.N. and Chand, R., (1995), "Public and Private Capital formation in Indian Agriculture" Economic and Political Weekly, 30(25):3165-3168.

Murukannaiah, S. 2006. Capital formation in agriculture in Chitradurga district of Karnataka state an economic analysis Unpublished M.Sc. (Agri.) Thesis, University of Agricultural Sciences, Dharwad.

Singh, M.M. and Mishra, M.L., 1974, Farm capital investment in Purnea district of Bihar. Eastern Econ., 120 (12): 509512.

Sidhu, R. S., Gill, S. S., 2006, "Agricultural Credit and Indebtedness in India: Some
Issue Indian Journal of Agricultural Economics, 51(2): 101- 109.

Yadav, A.K.S. 2002. Capital formation in agriculture in Bahirich district Unpublished Ph.D (Agri. Economics) Thesis, Banaras Hindu University Varanasi.

Mahantesh, Y., An economic analysis of private investment in dry land agriculture Ph.D (Agri. Economics) Thesis, University of Agricultural Sciences, Dharwad.

Swain, M., R. H. Patel, and Ojha M., 2011, Impacts of National Horticulture Mission Scheme in Rajasthan, Research Report No. 142, Agro-Economic Research Centre, S.P. University, V.V. Nagar, $125-132$.

\section{How to cite this article:}

Pradeep Joliya, V. Kamalvanshi, Saket Kushwaha and Shilpi. 2017. Determinants of Capital Formation in Agriculture: Hadoti Region of Rajasthan. Int.J.Curr.Microbiol.App.Sci. 6(7): 4239-4245. doi: https://doi.org/10.20546/ijcmas.2017.607.439 